\title{
Succession Planning, Employee Retention and Career Development Programmes in Selected Organisations in Ghana
}

Jonathan Tetteh

ServAid Consultancy and Business Services Limited,

Accra, Ghana

\section{Maxwell Amoah Asumeng}

Department of Psychology,

School of Social Sciences,

College of Humanities,

University of Ghana

Legon-Accra, Ghana.

\section{Correspondence:}

Department of Psychology,

School of Social Sciences,

College of Humanities,

University of Ghana

P.O. Box LG 84,

Legon, Accra. Ghana.

Email:

masumeng@ug.edu.gh

Tel.: +233248674405

\begin{abstract}
This paper examined the relationship between succession planning and employee retention, as well as the moderating role of career development program on the relationship between succession planning and employee retention. Using the cross-sectional design, 188 employees were conveniently sampled from four corporate organisations in Ghana to complete questionnaires on succession planning, employee retention and career development. The Hierarchical Multiple Regression was used to test the hypotheses. The results indicated that succession planning significantly predicted employee retention. Career development programmes also moderated the relationship. The results suggest that, the influence of succession planning on employee retention was moderated by career development programmes, such that, succession planning has more significant influence on employee retention when career development programmes are high rather than low. The study recommends the need for managers to develop strategic innovation in career development programmes to train and develop employees to enhance succession planning and employee retention in their organisations.
\end{abstract}

Keywords: Succession Planning, Training and Development, Employee Attrition, Job embeddedness, Human Capital Development.

\section{Introduction}

The $21^{\text {st }}$-century environment has been very erratic and chaotic characterized by employee poaching and organisational espionage. High-performance organisations do not develop by chance but rather a https://dx.doi.org/10.4314/ajmr. v27i1.9 
competitive workforce which is the result of years of effective planning and successful plan implementation (Ingram, 2014). Over the years, organisations have had issues with strengthening and retaining their workforce due to unpredicted events. These unpredicted events including demand fluctuations, leadership gap due to retirement, sickness, death and resignation, has led to a huge human resource gap. This phenomenon has made human resource planning a key management role in most organisations. Organisations have therefore begun quantifying these unpredicted events and are putting in place strategies and techniques to overcome them (Armstrong, 2003; Rothwell, 2005; Negrea, 2008).

Taylor (2012) identified succession planning as one of such strategies being used to address the issues of human resource gap. Succession planning is the attempt to plan for the right number and quality of managers and key-skilled employees to cover retirement, death, serious illness or promotion, and any new positions which may be created in future organisation plans (Sambrook, 2005). According to Hills (2009), it is a smart workforce management strategy that can drive retention of talent throughout the organisation and make sure that the organisation has the skills it needs in place to respond to the rapidly shifting sands that make up today's business environment. As such, succession planning and employee retention form part of human resource planning and have a direct impact on reducing staff turnover. Hewitt Associates (2004) identified retaining key talent or skills and succession planning as the two most important workforce planning issues.

Research in succession planning has also identified challenges that organisations have had with succession planning among which include career development of employees and intention to stay. (Chikumbi, 2011; Kataike, 2013; Miles and Dysart, 2008; Avanesh, 2011; Purcell, 2003).

In Ghana, top managers mostly show reluctance in training and developing the careers of junior staff towards future human resource gaps. This is because those trained are seen as a threat to the very existence of senior management. This has endangered the efforts and spirit of succession planning in the organisations within the country (Yanney, 2017). Lowan and Chisoro (2016) further observed that one of the major drawbacks in establishing a succession plan in developing countries is the lack of support from top company executives. Citing the example of corporate politics, Lowan and Chisoro (2016) indicating that instead of supporting a system approach to succession planning using career development opportunities, top managers rather use the corporate ladder to promote friends and allies, while punishing enemies, regardless of talent or qualifications.

Career development of employees is said to be directly linked to their satisfaction, such that, employees feel valued from their employers when allowed to develop their careers (Gerbamn, 2000). Employees who feel dissatisfied with their job are likely to leave the organisation just as the organisation would also want to retain its golden employees to achieve its objectives and long-term succession goals (Duggan \&Horton, 2004).

Career development encompasses various alternatives such as developing abilities, preserving current skills and getting ready 
for the future ahead of just receiving a promotion. The career development of employees has therefore gained greater policy attention in recent times. In an environment where organisations and individuals need to make more complex career and life choices, career development programmes have become even more important (Asumeng \& Assan, 2015; Kaya \& Ceylan, 2014).

From the background, it is imperative to highlight some essential gaps that will define the present study. First off, the issue of identifying and preparing the next generation of leadership talent is consistently cited by executives and boards as one of their most critical business priorities. Despite this, most organisations consistently rate their succession planning practices as less effective (Busine \& Watt, 2005). For example, between $40 \%$ and $65 \%$ of companies around the world have a formal succession planning process in place (Garman \& Glawe, 2008) which is to some extent woefully inadequate to say the least given its relevance in organisational development.

The total cost of employee turnover is about $150 \%$ of an employee's annual salary because of the cost of filling vacant positions, lost in productivity from vacant jobs and the cost of training new employees increases the operational cost of a firm (Ramlall, 2003). The negative effect of employee turnover and the challenges involved in retaining valuable employees is not exclusive of some developing countries like Ghana. Many organisations in Ghana have taken to poaching "already baked" talents from other organisations other than developing "homebred" talents. The question however is, are these people leaving because of dissatisfaction?
What are the triggers of the dissatisfaction? Could the absence of career development programmes and proper succession plans play a role? Could this not be a disincentive to existing employees who do not perceive any career and professional progression, hence decide to leave? This study tested a model where career development program moderates the relationship between succession planning and employee retention. Essentially, this study examined two key objectives:

- The effect of succession planning on employee retention.

- The moderating role career development programmes play in the relationship between succession planning and employee retention.

\section{Theoretical Background And Hypotheses The Agency Theory}

The Agency theory (Eisenhardt, 1989) provides a framework for understanding the relationship between succession planning, career development and employee retention. The theory proposes that agents, that is employees, are motivated by self-interests and might participate in the adverse selection or moral hazard, including staying or leaving the organisation, with the principals, that is employers; aptly known as agency cost. The theory suggests that this cost can be mitigated by integrating the employee's interests, that is career development, and being integrated into the succession plan program, with those of the employers, that is retention of skilled employees, who can also be integrated into the succession plan (Cruz et al., 2010). On the basis of this theory, offering employee development activities, such as career development through suc- 
cession plans, become necessary to discourage the turnover intentions which practices cost the organisations adversely and make it lose their competitive edge.

Thus, development activities alter the employee's intention to quit the firm which results in minimizing the sources of agency cost (Cummings et al., 2007). According to Gomez-Mejia et al. (2001), agency costs, which is skilled workforce turnover, can be controlled by providing incentives and bonuses to workers mainly in the form of professional growth.

This study, therefore, proposes that the agency theory predicts the employee's behaviours toward making turnover intentions and how employers plan strategies to control them while strengthening the relationship of principal-agent, mainly by providing the employees development opportunities, that is succession planning, career development and job security, as a way to mitigate the turnover risk.

\section{Relationship between succession planning and employee retention}

The lack of a "fill-in scheme" in most organisations in Ghana specifically and Africa at large has spawned technical hitches filling in vacancies in such organisations (Mensah et al. 2016; Nana, 2013). This leads to profound displeasure among employees and the result is decreased performance and retention rates among high performers. As a result, research on employee retention has received some attention (Jiang \& Klein, 2002) especially in the context of succession planning. Hassan and Siddiqui (2019), investigated the impact of effective succession planning practices on employee retention: exploring the mediating roles using 300 respondents who are serving in the middle and lower level of management in the private organizations in Pakistan. Their findings revealed that effective succession planning practices had a meaningful and favourable connection with employee retention.

The Aberdeen Group (2005) also did a survey looking at retention and succession planning in the corporate workplace. They found that a clear correlation exists between executive retention and companies with formalized retention and succession programs. More specifically, the survey revealed that a strong majority of companies that reported $1 \%$ to $5 \%$ average turnover rates had formal retention $(89 \%)$ and succession program respectively $(84 \%)$. The question however is; could the same finding be established in the case of non-management employees? Another study by Eshiteti, Okaka, Maragi and Akerele (2013) to establish the effects of succession planning programs on staff retention in the sugar companies of Western Province, Kenya revealed that more employees had high job satisfaction because of the perceived presence of a succession planning process, which gives them hope of being next in line of management. This according to them had a positive effect on the retention of staff in the sugar firm.

Another study by Tunje (2014) looked at succession planning practices and employee retention in large media houses in Kenya. The study revealed that there is a positive relationship between succession planning practices and employee retention. Additionally, the findings suggested that succession planning practices are implemented in the media houses though only for key positions and not all positions. What could be the outcome of suc- 
cession planning practices if it is applied to all positions, would the outcome be the same?

\section{Hypothesis 1: Succession planning will significantly predict employee retention.}

\section{Career development programme as a moderator in the relationship between succession planning and employee retention}

Studies suggest that, for an organisation to have a successful succession planning program, it must identify its long-term goal and by so doing identify and understand the developmental needs of its employees (Hutchings, Zhu, Brain, Cooper, Zhang \& Shao, 2009; Heathfield, 2010). As well, organisations must ensure that all key employees understand their career paths and the roles they are being developed to fill (Bowes, 2008). According to Purcell (2003) providing career opportunities is one of the surest ways to a successful succession planning program. In a study among information technology workers in the United States, Liu (2004) found that the provision and availability of development opportunities as a human resource supportive tool enhanced loyalty among the workers and by extension improved employee retention. Additionally, a study by Kataike (2013) found that training opportunities emerged as one of the factors which affected the retention of employees of which management had neglected. Ghazali (2010) also observed from their study that human resource practices including training and development of employees had a significant relationship with intention to stay. Further, Mapelu and Jumah (2013) in a study revealed that employee development significantly affected employee turnover positively. Training and development, therefore, is an investment in employees' productivity and retention as it provides for career progression and job satisfaction of employees over a long period, hence a good way to increase the motivation of employees and retain skilled workers within organisations (Bowes, 2008; Hutchings, Zhu, Brain, Cooper, Zhang \& Shao, 2009).

Employers who have more skillful employees as a result of career development can expect them to navigate their internal labour markets more effectively which can reduce the problems associated with succession (Cedefop, 2008). Also, when struggling employees benefit from such additional job-related knowledge they feel loved by the organisation hence influences them to be with the organisation. The conclusion drawn from these studies suggests that career development can significantly influence the relationship between succession planning and employee retention.

\section{Hypothesis 2: Career development programme will moderate the relationship between succession planning and employee retention such that, it will enhance the relationship.}

The proposed conceptual model indicates that succession planning will significantly predict employee retention. Also, career development programme is proposed to moderate the relationship between succession planning and employee retention. 


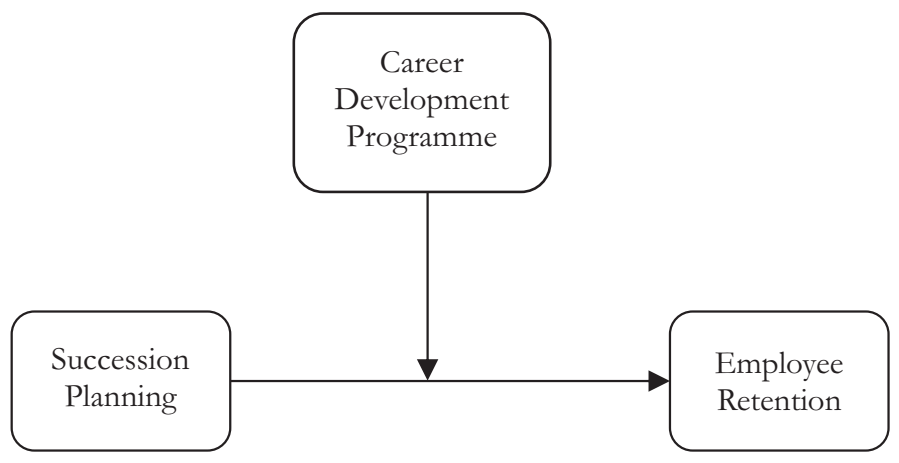

\section{Methodology}

\section{Research Design and Setting}

The cross-sectional survey design was used for the study. Participants in the study were drawn from varying backgrounds, different organisations, job positions, departments, age, tenure and gender at one point in time. The study was conducted in the Greater Accra Region of Ghana with an emphasis on both the manufacturing and service sectors of private and public organisations. The reason is that most studies in Ghana concentrate on just the manufacturing sector and mostly in private organisations; regardless of the significant contributions of the service sector in Ghana.

\section{Population}

The population for this study was selected from the Greater Accra Region, the industrial hub of Ghana, which hosts the seat of government. Accra is the second most populated city in Ghana, with many inhabitants from different parts of the country working in various organisations within the Greater Accra Region. Most of the public and private organisations are concentrated in Accra and Tema than in the other regions in Ghana. Four main organisations were selected based on their proximity, accessibility and their willing- ness to take part in the study. The four main organisations used for the study include two public sector organisations (Cocoa Processing Company \& Ghana Civil Aviation Authority) and another two from the private sector (Pioneer Food Cannery \& Ecobank Ghana Limited). Ghana Civil Aviation Authority and Cocoa Processing Company were specifically chosen because of their history of change of leadership with every change of government and the high political influence in their recruitment exercise. These changes of leadership subsequently come with changes in policies which normally creates uncertainty among employees affecting their behaviour. Pioneer Food Cannery and Ecobank Ghana Limited were also selected as the population of interest in view of the fact that, they are vibrant on the job market and very competitive. Finally, these companies were selected because they serve a large market in Ghana. As suggested by Hofstede, Neuijen, Ohayv and Sanders (1990), instead of one corporation in many countries, we should study many different organisations in one and the same country. To obtain better reliability and validity of the data, the study used a sample from different sectors on one hand and samples from different organisations on the other hand (Yuorpor, 
2013).

\section{Sample and Procedure}

The convenience sampling technique was used in selecting the organisations and participants in this study. This was because, the study considered organisations with succession plans, geographical proximity, their availability and accessibility at the time of the study, and also their willingness to volunteer for the study (Dörnyei; 2007). To collect the data, introductory letters were sent to the organizations to seek their authorization for this study. Upon granting permission to carry out the study, the employees were informed about the purpose of this study and asked to voluntarily consent to participate. Employees who agreed to participate in the study were assured of confidentiality regarding their personal information provided to the questions asked. Two hundred and twenty (220) questionnaires were given to the participants to complete within 30 minutes after which they were retrieved, scored and analyzed. Out of this total, one hundred and ninety-seven (197) were completed and returned. However, only one hundred and eighty-eight (188) were used in the analysis, resulting in a response rate of $85.45 \%$. Nine (9) questionnaires were excluded from the data analysis due to missing values as responses to some items in the questionnaires were left blank.

\section{Survey Instruments \\ Succession Planning}

A 25-item scale (Salaman, 2014) was used to measure succession planning. It was used in her study titled, "Relationship between succession planning practices and employee retention in large media houses in Kenya." Responses were scored on a 5-point Likert scale ranging from 1 (Strongly Disagree) to 5 (Strongly Agree). Examples of the items include: "In my organisation, succession planning puts into consideration all key positions" and "In my organisation, employees are internally offered internship opportunities to assist them to advance their careers". The Cronbach alpha value of the scale was .84 .

\section{Employee Retention}

An 11-item scale (Kyndt, Dochy, Michielsen \& Moeyaert, 2009) was used to measure employee retention. It was used in their study of IT workers titled, "Employee Retention: Organisational and Personal Perspectives". Responses were scored on a 5-point Likert scale ranging from 1 (Strongly Disagree) to 5 (Strongly Agree). Examples of the items include, "I foresee a future for myself within this company" and "It doesn't matter if I work. for this company or another, as long as I have work." The Cronbach alpha value of the scale was.75.

\section{Career Development Programme}

Also, a 12-item scale (Ameeq \& Hanif, 2013) was used to measure career development in the context of organisational training and development. Respondents were asked to report how much they agreed with the items on a scale from 1 (strongly disagree) to 5 (strongly agree). Examples of items on the scale include, "Our organisation conducts extensive training programs for its employees in all aspects of quality" and "There are formal training programs to teach new employees the skills they need to perform their jobs". The Cronbach alpha value of the scale was 0.88 .

\section{Data Collection Procedure}

A letter seeking permission to conduct the study was sent to the Human Resource 
Department of the selected organizations for approval, followed by an informed consent form to employees who voluntarily agreed to participate in the study. Questionnaires were put in an envelope and given to Human Resource Officers in the selected organisation who assisted in administering them. The questionnaires covered the introductory part explaining the purpose of the study, instructions for completing the questionnaires, the demographic details of participants and the study measures. Participants were assured of confidentiality and anonymity of their responses. The data collection lasted for four weeks. Participants submitted their responses at the Human Resource Departments which were put in envelops, sealed and collected personally by the researchers.

\section{Ethical consideration}

The consent of participants was sought by making available an informed consent form after which willing participants accepted to take part in the study. It was ensured that the information collected from participants were kept confidential. Steps were taken to ensure that physical or psychological harm was not caused to the participants. The 2001 American Psychological Association guidelines on confidentiality and informed consent were duly followed.

\section{Data Analysis}

Data were analysed using the Statistical Package of Social Sciences (SPSS) version 22.0. The analyses were conducted in two parts. The first part was the preliminary analysis while the second part was the test of the hypothesized model in the study. The preliminary analysis comprised descriptive and reliability analysis, factor analysis and correlation analysis of the study variables.

In the descriptive statistical analysis, firstly, the means, standard deviations, minimum and maximum scores of participants on the variables were examined. Also, it examined the skewness and kurtosis values of the measures to determine whether the scores were normally distributed to warrant the use of parametric statistics data analytic techniques. Secondly, reliability analysis of the measures was run to determine their internal consistency using the Cronbach alpha values. To establish the construct validity and whether items that make up the measures would yield factor loadings that show they could be considered part of a single construct, factor analysis was done using the principal component analysis. Reliability analysis and factor analysis would help to determine if the scales have acceptable psychometric properties, and measured what they intended to measure in Ghanaian organisational settings. Finally, correlation analysis was done using the Person Product Moment Correlation to establish the relationships between the measures, for further regression analysis for testing the hypothesized model for the study.

The hypothesized model of the study was tested using the hierarchical multiple regression and moderation analysis. Hierarchical multiple regression analysis was run to assess whether the dependent variable can be predicted from a set of independent (or predictor) variables and further to increase the efficiency of analysis. In the moderation analysis, the four stages proposed by Baron and Kenny (1986) were duly followed. Firstly, the 
variables (succession planning (independent/predictor variable); career development programme (moderating variable/moderator; and employee retention (dependent variable/outcome variable) were standardized to clean the data of the effect of any multicollinearity. Secondly, the interaction effect (predictor X moderator) was calculated using the standardized values. Thirdly, the outcome variable was regressed; this was done by first entering the predictor variable in the first block, secondly, the moderator was entered into the second block and thirdly, the interaction effect was entered into the third block. In the fourth and final stage of the moderation analysis, the dependent variable was regressed on the predictor, moderator and the interaction between the two. The outcome of this process allowed for analysis of the two hypotheses/test of the hypothesized model of the study.

\section{Results And Discussion Demographic Characteristics of Respondents}

The demographic characteristics of respondents are given in terms of their age, highest education, gender, tenure, job positions in the organisations and type of organisations they work. Table 1 provides details of the demographic characteristics of the respondents and the type of organisations they work in.

Table 1: Demographic Characteristics Respondents

\begin{tabular}{|c|c|c|c|c|c|}
\hline Variable & Freq. & $\%$ & Variable & Freq. & $\%$ \\
\hline Age & & & Tenure & & \\
\hline $20-29$ years & 59 & $31.4 \%$ & $0-2$ years & 50 & $26.6 \%$ \\
\hline $30-39$ years & 45 & $23.9 \%$ & $3-5$ years & 41 & $21.8 \%$ \\
\hline $40-49$ years & 52 & $27.7 \%$ & $6-10$ years & 45 & $23.9 \%$ \\
\hline 50 years above & 32 & $17.0 \%$ & 11 years above & 52 & $27.7 \%$ \\
\hline Highest Education & & & Job Position & & \\
\hline Masters & 50 & $26.6 \%$ & Management & 24 & $12.8 \%$ \\
\hline Bachelor's Degree & 100 & $53.2 \%$ & Senior Staff & 73 & $38.8 \%$ \\
\hline HND & 38 & $20.2 \%$ & Junior Staff & 91 & $48.4 \%$ \\
\hline Gender & & & Type of Orga & & \\
\hline Male & 99 & $52.7 \%$ & Pubic & 89 & $47.34 \%$ \\
\hline Female & 89 & $47.3 \%$ & Private & 99 & $52.66 \%$ \\
\hline
\end{tabular}

Source: Constructed by authors based on field data

From Table 1, the age of the respondents ranged from a minimum of 20 years to 50 years and above, with the majority $(31.4 \%)$ of them being between the ages of 20 to 29 years. On their levels of education, the majority of the respondents $(53.2 \%)$ had a bachelor's degree with a few of them
$(20.2 \%)$ having at least a higher national diploma. Males (52.7\%) were more than females $(47.3 \%)$ in the sample. The difference is however not too much as to make the sample overly skewed towards males. With regards to the years of stay in the selected organisations, most of the 
respondents $(45.7 \%)$ have spent between 3 to 10 years in their orgainsations whiles $27.7 \%$ of them have spent more than 11years with their organisations. This implies that most of the respondents have spent enough time in their oranisations to know the policies and practices of their organisations. Table 2 further shows that majority of the respondents are junior staff $(48.4 \%$ ) whiles $12.8 \%$ and $38.8 \%$ are managers and senior staff respectively.
The data also suggests that $52.66 \%$ of the respondents are in private organisations whiles $47.34 \%$ are in the public organisation.

\section{Descriptive Statistics and Reliability} Analysis

Descriptive data of the study was obtained from the participants' responses and the findings are presented in Table 2.

Table 2: Summary of Descriptive Statistics and Reliability Indices of Study Variables $(\mathrm{N}=188)$

\begin{tabular}{|c|c|c|c|c|c|c|c|}
\hline Variables & Mean & SD & Minimum & Maximum & Skewness & Kurtosis & Alpha \\
\hline Succession Planning & 85.73 & 12.62 & 46 & 112 & -.73 & .40 & .86 \\
\hline Employee Retention & 40.13 & 5.23 & 20 & 55 & -.40 & 1.29 & .63 \\
\hline Career Development Program & 47.47 & 6.76 & 21 & 59 & -.83 & .89 & .90 \\
\hline
\end{tabular}

From Table 2, the results indicate that all the variables in the study were normally distributed as the skewness and kurtosis values were between $-2 /+2$. Hence the data were amenable to the appropriate parametric statistical analysis. Also, in regression analysis, the dependent variable must be normally distributed (Tabachnick, \& Fidel, 2001). The Cronbach's alpha values observed for the variables were $.86, .63$, and .90 yielding reasonably acceptable results, hence the scales were reliable. The mean values indicated that on the average employees perceived that succession planning was practiced in their organisation and they were more likely to stay with the organisation. The mean values also indicated that on the average employees perceived that career development programs were provided by their organisations though the value is low.
Factor Analysis of Succession Planning, Employee Retention and Career Development Programmes

A principal component factor analysis of the items in the scales was conducted. This was done to ensure that the scales have construct validity. Thus, to ensure that the scales measured what they intended to measure (Tabachnick \& Fidell, 2001) in the Ghanaian organisational context. The principal component analysis revealed the presence of components with eigenvalues exceeding 1, explaining for a cumulative variance of $57.18 \%, 57.53 \%$ and $47 \%$ for succession planning, employee retention and career development program respectively. Tables 3 to 5 show the results of the principal component analysis of the items of the scales used in the study. 
Table 3: Factor loadings based on a principal component analysis of the twenty-five items on the Succession Planning Scale $(\mathrm{N}=188)$.

1. In my organisation, succession planning puts into consideration all key positions.

2. In my organisation, performance appraisals are always conducted annually.

3. Job rotation is well implemented across all departments in my organisation.

4. In my organisation, rewards are given to all employees without any form of discrimination.

5. Bonuses and incentives are benefits given to all employees in my organisation based on their performance.

6. In my organisation, management supports employees who wish to advance in their careers through the Education Policy and sponsorships for training.

7. In my organisation, employee career paths are clearly defined and are available from the HR Department.

8. In my organisation, every year employees are always given feedback about their talent Reviews.

9. In my organisation, training and development opportunities are available to all employees.

10. In my organisation, it is evident that managers and supervisors have effective management and leadership skills.

11. In my organisation, occasionally employees are allowed to define their rewards.

12. In my organisation, mentoring and coaching are well practiced by most managers and supervisors.

13. In my organisation, talented employees are always considered for sponsorships.

14. In my organisation, there are opportunities for employees to continuously improve their skills.

15. In my organisation, the pay and grading structures allow employees to defined their own remunerations.

16. In my organisation, succession planning is strictly considered for top level management.

17. In my organisation, employees are usually recruited from diverse demographic backgrounds.

18. In my organisation, the succession plan encourages promotion from within strictly based on merit.

19. In my organisation, rewards are always given to talented employees.

20. In my organisation, any changes in HR policies are communicated to all employees.

21. Talented employees are always attracted to join my organisation due to its good reputation in retaining talent.

22. In my organisation, diversity management policy disregards any form of discrimination against gender, religion and sex.

23. In my organisation, there are flexible rewards and benefits that cater for family and individual needs/preferences.

24. In my organisation, we have an "open door policy" which enables smooth communication between management and employees.

25. In my organisation, employees are internally offered internship opportunities to assist them advance their careers. 
Table 4: Factor loadings based on a principal component analysis of the eleven items on the Employee Retention Scale ( $\mathrm{N}=188)$.

\section{Item}

Factor loading

1. I'm planning on working for another company within three years.

2. Within this company my work gives me satisfaction.

3. If I wanted to do another job or function, I would look first at the possibilities within this company

4. I see a future for myself within this company.

5. It doesn't matter if I'm working for this company or another, as long as I have work.

6. If it were up to me, I will definitely be working for this company for the next five years.

7. If I could start over again, I would choose to work for another company.

8. If I received an attractive job offer from another company, I would take the job.

9. The work I'm doing is very important to me.

10. I love working for this company.

11. I have checked out a job in another company previously.

Extraction method: Principal Component Analysis

Table 5: Factor loadings based on a principal component analysis of the twelve items on the Career Development Programme (N=188).

1. Our organisation conducts extensive training programs for its employees in all .72 aspects of quality.

2. Employees in each job will normally go through training programs every year.

3. Training needs are identified through a formal performance appraisal mechanism.

4. There are formal training programs to teach new employees the skills they need to perform their jobs.

5. I believe the social circle in the firm is expanding due to participation in the training program.

6. I believe my promotion is a result of the induction of the training program.

7. I believe that my set targets and objective are attained and identified by the firm through training programs.

8. I believe that my pay scale has increased as a result of participation in appropriate training program or skill upgrade.

9. I believe that more career paths will emerge and more opportunities will come my way after participating in any training program.

10. Training has helped me in improving my overall required skills for work.

11. In our organisation, Training motivates employees to be more committed towards organizational goals.

12. My career path is more in shape due to my participation in the training program.

Extraction method: Principal Component Analysis 
These results indicate reasonably good measures/scales, and additionally, as indicated by their high-reliability coefficients (Alpha values, Table 3), the scales were valid instruments that measured what they intended to measure; succession planning, employee retention and career development program (Tabachnick \& Fidell, 2001) in the Ghanaian organisational context.

Pearson Correlation among Study Variables

A Pearson correlation was done to establish the relationships between the study variables. The summary of the outcome is presented in Table 6 .

Table 6: Pearson Correlation Matrix of the Relationships between Study Variables

\begin{tabular}{llll}
\hline Variables & 1 & 2 & 3 \\
\hline 1. Succession Planning & - & - & - \\
2. Employee Retention & $.48^{* *}$ & - & - \\
3. Career Development Program & $.68^{* *}$ & $.45^{* *}$ & - \\
\hline$* *$ Correlation is significant at the 0.01 level (1-tailed).
\end{tabular}

Table 6 indicates a positively moderate correlation between succession planning and employee retention $(\mathrm{r}=.48, \mathrm{p}<.01)$. Table 7 also indicates a positively high correlation between succession planning and career development program $(\mathrm{r}=.68$, $\mathrm{p}<.01)$ and a positively moderate correlation between employee retention and career development program $(\mathrm{r}=.45$, $\mathrm{p}<.01)$.

Table 7: Summary of the Hierarchical Multiple Regression for Career Development Programme on the Relationship between Succession Planning and Employee Retention.

\begin{tabular}{llllll}
\hline Model & $B$ & $S E B$ & $\beta$ & F & $p$ \\
\hline Step1: Constant & 29.952 & 2.599 & & & .000 \\
SP & .115 & .029 & .278 & 15.636 & .000 \\
Step2: Constant & 23.075 & 3.061 & & & .000 \\
SP & .069 & .030 & .167 & 16.053 & .025 \\
CDP & .227 & .058 & .288 & & .000 \\
Step3: Constant & 35.492 & 4.547 & & & .000 \\
SP & -.109 & -.057 & -.264 & 15.723 & .060 \\
CDP & -.010 & .086 & -.013 & & .909 \\
SP*CDP & .003 & .001 & .657 & & .000 \\
\hline$R^{2}=.078, .148$ and .204 for steps 1,2 and 3 respectively. $\Delta R^{2}=.073, .139$ and .191 for steps 1,2 and 3 \\
respectively $* *<.01$
\end{tabular}

Hypotheses/Model Testing

The hypothesized model depicting the two hypotheses was tested using the hierarchical multiple regression analysis and moderation analysis. This was to determine the extent to which succession 
planning influences employee retention and the role career development plays in that relationship. This statistical analytic technique was used after a prerequisite significant correlation was established between the study variables (see Table 6). As indicated earlier, a four-stage approach (Baron \& Kenny, 1986) was used in running the analysis. The result is presented in Table 7.

From Table 7, the analysis indicated that the model in step one was significant accounting for a $7.8 \%$ variance in explaining employee retention $\left[F_{(1,180}=15.636\right.$, $\left.\varrho<.01, \mathrm{R}^{2}=.078\right]$. Thus, succession planning significantly predicted employee retention $(\beta=.278, p<.01)$. Therefore, hypothesis one was confirmed. At step 2 of the model, career development program made a significant contribution $(13.9 \%)$ in explaining the variance in employee retention, $\left[F_{(2,185)}=16.053, \varrho<.01\right.$, $\left.\Delta \mathrm{R}^{2}=.139\right]$. Thus, career development program significantly predicted employee retention $(\beta=.288, p<.01)$. The third step revealed that the model accounted for $19.1 \%$ variance in employee retention $\left[F_{(3,}\right.$ $\left.{ }_{184)}=15.723, \varrho<.01, \Delta \mathrm{R}^{2}=.191\right]$. Hence, in line with the prediction made, the interaction between succession planning and career development program was significant $(\beta=657, \varrho<.01)$. Thus, hypothesis two which states that career development programme will moderate the relationship between succession planning and employee retention was supported.

Aiken and West (1991) recommended that, for an appropriate interpretation of an interaction effect, a simple slope analysis should be conducted. Therefore, since an interaction effect was established in this moderation analysis, and in line with the view of Aiken and West (1991), a simple slope analysis was conducted (see Figure 2). Upon inspection of Figure 2, the interaction results indicated that the influence of succession planning on employee retention was moderated by career development programme, such that, the higher the level of the career development program, the greater the effect of succession planning on employee retention. However, as career development programme reduces, the effect of succession planning on employee retention also reduced.

\section{Discussions}

The focus of this study was to investigate the relationship between succession planning and employee retention. Also, the role of career development programme in the succession planning-employee retention relationship was explored. The first hypothesis sought to investigate whether succession planning will significantly predict employee retention. The results indicated that indeed succession planning significantly predicted employee retention positively $(\beta=.278, p<.01)$. Specifically, succession planning accounted for $7.8 \%$ of the variance in explaining employee retention $\left[F_{(1,180)}=15.636, \varrho<.01, \mathrm{R}^{2}=\right.$ $.078]$. Thus, organisations that put in place proper succession planning policies are more likely to influence their employees' decisions to stay with the organisation. Succession planning may have led to the promotion of some employees and such employees may see such "move" as a kind of motivation, hence their decision to stay. Further, the finding is consistent with many other findings as reviewed in the literature (Aberdeen Group, 2005; Eshiteti et al. 2013; Hassan \& Siddiqui, 2019). This finding contributes to the existing body of research by revealing that, 
formal succession planning program indeed helps in the retention of valuable workers as well as act as a tool to attract other potential employees. It has emerged as a strong factor influencing staff retention. Organisations that properly manage talent, through succession planning, are more likely to have the most success at keeping their employees loyal, which inevitably leads to a lower turnover rate, that is, a higher retention rate.

Figure 2: Summary of simple slope graph of career development moderating the relationship between succession planning and employee retention

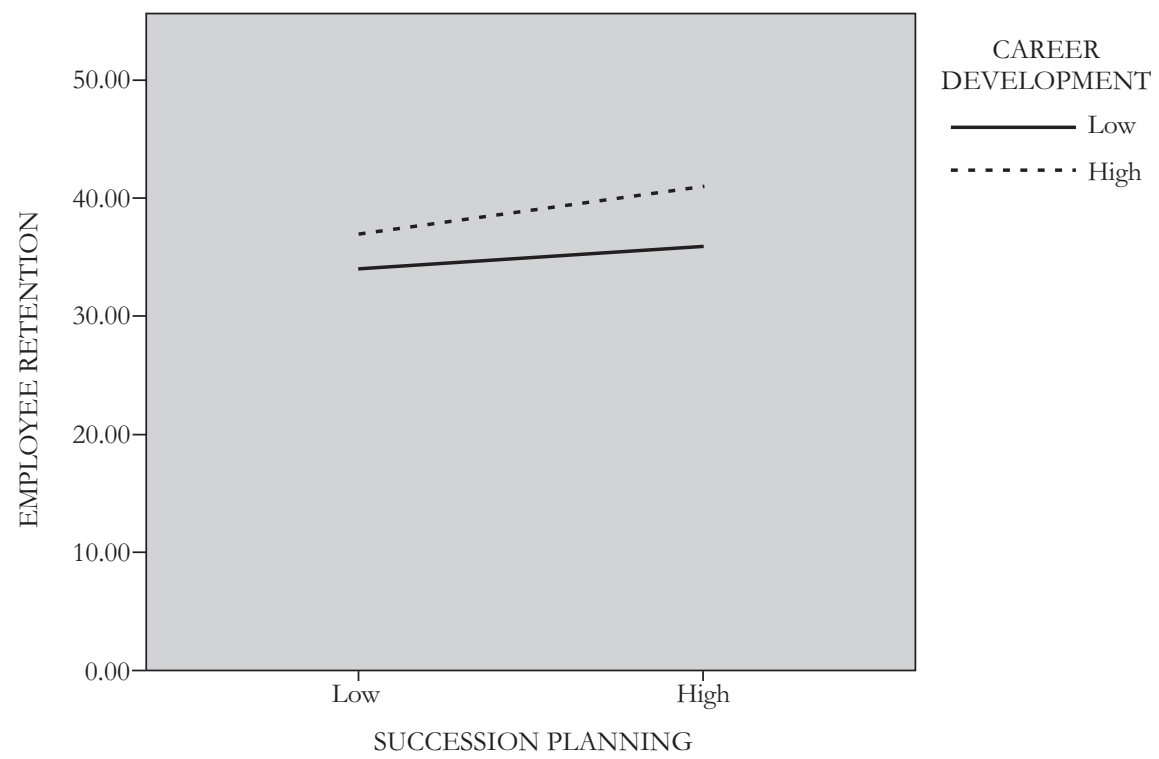

Further, whiles the results of the analysis indicate that succession planning independently predicts employee retention, career development program plays a significant role in that relationship by strengthening it, such that, a higher level of career development program increases the retention rate of the employees. The moderation hypothesis was anticipated based on the premise that career development program according to the literature has a positive effect on employee retention. With this rationale, support was found for the moderating role of career development pro- gram on the succession planning-employee retention relationship in the current study. The result of this study is in line with the results of previous studies conducted as reviewed in the literature (Hutchings et al, 2009; Ghazali, 2010; Mapelu \& Jumah, 2013). The reasons for this finding could be that career development programs are not just a sign of the organisation's commitment to employees but also a major mechanism for attracting, motivating, retaining good quality employees and also satisfying the career progression needs of the employees. These, 
therefore, influence the decision of the employee to stay with the organisation. As stated by Purcell (2003), providing career development opportunities is one of the surest ways to a successful succession planning programme.

\section{Limitations, Conclusion, Implication of Findings and Future Research Direction}

\section{Limitations}

The study utilized the cross-sectional design which limited its ability to draw cause-effect relationships. However, the moderating hypotheses help in establishing a relationship close to a causeeffect relationship (Field, 2005). This is because the moderation helped to identify the conditions under which the relationship between the predictor and outcome variables can be strengthened or weekend. This, therefore, enhances the ability to better predict (Baron \& Kenny, 1986). Hence the test of moderation in the current study helps to reduce to some extent the defects that come about as a result of the inability to draw a cause-effect relationship.

Also, the researchers largely employed the use of regression in testing the various hypotheses establishing the relationships between the variables. The researchers took this decision with the assumption that the relationships were linear. However, it will not be farfetched that a possible non-linear relationship could exist between the variables and therefore testing these relationships adopting nonlinear regression models is likely to lead to different results.

\section{Conclusion}

In line with the findings, the study concludes that succession planning significantly predicts employee retention. Further, it provides empirical evidence for career development program as a moderator in the relationship between succession planning and employee retention, to the extent that it strengthens the relationship. Therefore, organisations may formally fuse career development programmes into its system and policies to increase the effect of succession planning on employee retention.

\section{Implication of Findings}

The findings of this study add on to the existing body of knowledge on the general subject of succession planning, employee retention and career development program in Ghana. Since there is inadequate literature on succession planning practice in Ghana, the findings of the study provide benchmark data that can be used for future research.

Furthermore, employees as it is well known, form the backbone for organisational growth and survival. For organisations to keep their scarce employees and even produce a pool of best talents, management needs to view succession planning as a strategic part of an organisation's policy to prepare employees for any future exit. This is more so as some employees see such strategic policies as a form of promotion in waiting. This if done will motivate and as well influence their decision to stay with their organisation.

Additionally, it has also become very important for organisations and their managers to attach greater importance to the career development of their em- 
ployees. This study has revealed that career development of employees strengthens the relationship between succession planning and employee retention. One thing every employee wishes for in life is to have a career progression. This explains why so many workers today are pursuing higher learning and more difficult training programs to fulfill this wish. When employees find themselves in organisations that consider their career progression in terms of their career development, they will be willing to take advantage of such opportunities. More so when this opportunity is imbedded in the succession policy of the organisation. The need for a strategic innovation of career development programs to train and develop employees in organisations cannot be underestimated. Organisations that want to stay competitive, grow and survive in this turbulent business need to give the career develop-

\section{REFERENCES}

Aberdeen Group (2005). Retaining Talent: Retention and Succession in the Corporate Workforce. Boston: Massachusetts.

Abdillea, M. H. (2013). The Effects of Strategic Succession Planning on Family Owned Business in Kenya. Unpublished dissertation, School of Business: University of Nairobi.

Aiken, L. S. \& West, S. G. (1991). Multiple Regression: Testing and interpreting inter-actions. Newbury Park, California: SAGE Publications.

Ameeq, U. A. \& Hanif, F. (2013). Impact of Training on Employee's Development and Performance in the Hotel Industry of Lahore, Pakistan. Journal of Business Studies Quarterly, 4, 68-82.

Armstrong, M. (2003). A Handbook of Human Resource Management Practice: (9th Edition), ment of their employees a favourable consideration. Consequently, if organisations embrace career development practices they would not only improve knowledge, skills and the abilities of their current and potential employees but also enhance the retention of quality employees.

\section{Future Research Direction}

The researchers suggest that a future study could incorporate the use of longitudinal design to improve the ability to make stronger causal statements than were found in this current study. Further, future research can exploit the use of non-linear regression models as well as different operationalization of the variables such as career development program, and also allow for the use of other analytical techniques to test the hypothesized relationships for this study.

London, Cambrian Printers Ltd.

Asumeng, M. A, \& Assan, E.. (2015). What it means to work hard for career progression: A study of corporate managers in Ghana. British Journal of Psychology Research, 3(2)1934.

Avanesh, N. (201 1). A study on Succession Planning and Its Impact On Organizational Performance in the IT Sector. Journal of Arts, Science \& Commerce, 2(1), 1-12.

Baron, R. M., \& Kenny, D. A. (1986). The moderator-mediator variable distinction in social psychological research: Conceptual, strategic, and statistical considerations. Journal of Personality and Social Psychology, 51(6), 1173-1182.

Bowes, B. (2008). Employees Development Programs Help Companies Achieve Greater Success. CMA Management, 13-14. 
Capelli, P. (2000). A market driven approach to retaining talent. Harvard Business Review, JanFeb, 101-111.

CEDEFOP (2008). Career development at work: A review of career guide to supportpeople in employment, European Union.

Cowin, L. (2002). The effects of nurses` job satisfaction on retention: An Australian perspective. Jona, 32(5), 283-29.

Cruz, C. C., Gomez-Mejia, L. R., \& Becerra, M. (2010). Perceptions of benevolence and the design of agency contracts: CEO-TMT relationships in family firms. Academy of $\mathrm{Ma}$ nagement Journal, 53, 69-89.

Cummings, D., Siegel, D.S. \& Wright, M. (2007). Private equity, leveraged buyouts and governance. Journal of Corporate Finance, 13 (4), 439-460.

Dörnyei, Z. (2007). Research methods in applied linguistics. New York: Oxford University Press.

Duggan, B. \& Horton, D. (2004). Strategic Recruitment and Retention: Competitive Advantage and Return on Investment. Marathon Human Resources Consulting Group Limited. Retrieved from http://www.mora thonhrcg.com/articles/Strategic\% $\% 20$ Recru itment $\% 20$ and $\% 20$ Retention

Egan, T. M., Yang, B. \& Bartlett, K. R. (2004). The effects of organizational learning culture and job satisfaction on motivation to transfer learning and turnover intention. Human Resource Development Quarterly, 15(3), 279-301.

Eisenhardt, K. (1989). Agency Theory: and Assessment Review. The Academy of Management Review, 14(1), 57-74.

Eshiteti N. S., Okaka O., Maragia N. S., Odera O., \& Akerele K. E. (2013). Effects of Succession Planning Programs on Staff Retention. Mediterranean Journal of Social Sciences, 4(6).

Field, A. P. (2005). Discovering statistics using SPSS (2nd ed.). London: Sage.

Gerbman, R. V. (2000). Corporate Universities 101. HR Magazine, 45(2), 101-106.

Ghazali, H. (2010). Employee intention to leave a job: A case of Malaysian fast-food in- dustry. Unpublished Manuscript, University of Waikato.

Gomez-Mejia, L., Nunez-Nickel, M., \& Gutierrez, I. (2001). The role of family ties in agency contracts. Academy of Management Journal, 44(1), 81-95.

Heathfield, M. S. (2010). Succession Planning. Retrieved on March 13, 2015 from http:// humanresources.about.com

Hewitt Associates (2004). What makes a best employer? Insights and Findings from Hewitt's Global Best Employer's Study, Hewitt Associates, 1-28.

Hofstede, G., Neuijen, B., Ohayv, D. D., \& Sanders, G. (1990). Measuring organisational culture: a qualitative and quantitative study across twenty cases. Administrative Science Quarterly, 35(2), 286-316.

Hutchings, K., Zhu, C.J., Brain, K., Cooper, Y. \& Zhang, S. S. (2009). Perceptions of the Effectiveness of Training and Development of Grey-Collar Workers in the People's Republic of China. Human Resource Development International, 12(3), 279-296.

Ingram, D. (2014). Examples of Organisational Planning. Retrieved on May 23, 2017 from http://smallbusiness.chron.com

Jiang, J. \& Klein, G. (2002). Strategic Information and Strategic Decision Making. The EIS/CEO Interface in Smaller Manufacturing Companies Information and Management, 40, 19.

Kaya, D. \& Ceylan, B. (2014). An Empirical Study on the Role of Career Development Programs in Organisations and Organisational Commitment on Job Satisfaction of Employees. American Journal of Business and Management, 3(3), 178-191.

Kyndt, E., Dochy, F., Michielsen, M. \& Moeyaert, B. (2009). Employee retention: organisational and personal perspectives. Vocations and Learning, 2(3), 195-215.

Lowan, V. \& Chisoro, C. (2016). The Impact of Succession Planning for Business Survival: A Case of Kwalita Business Consultants, Johannesburg (South Africa). Arabian Journal of Business and Management Review, 5(12), 63-90. 
Liu, W. (2004). Perceived Organisation Support: Linking Human Resource Management Practices with Important Work Outcomes. Unpublished Doctoral Dissertation, University of Maryland: College Park.

Mapelu, C. I. \& Jumah, L. (2013). Effect of Training and Development on Employee Turnover in Selected Medium Sized Hotels in Kisumu City, Kenya. Journal of Tourism, Hospitality and Sports, 1, 43-48.

Mensah, J., Bawole, J. \& Wedchayanon, N. (2016). Unlocking the "Black Box" in the Talent Management Employee Performance Relationship: Evidence from Ghana. Management Research Review, 39, 1546 - 1566.

Miles, S. A \& Dysart, T. L. (2008). Roadmap for successful succession planning: Directors \& Boards. First Quarter, 57-59

Nana, Y. O. (2013). Talent management: A Buddle of Hurdles. Public Policy and Administration Research Paper, 3(8), 45-47.

Negrea, S. (2008). Succession planning: A necessity for community colleges. Institute for Community College Development. New York, NY.

Purcell, J. (2003). Understanding the people and performance link: unlocking the black box. London: CIPD.

Ramlall, S. (2003). Managing Employee Retention as a Strategy for Increasing Organisational Competitiveness. Applied H.R.M Research, 8(2), 63- 72.

Rothwell, W. J. (2005). Effective succession planning: Ensuring leadership continuity and building talent from within (3rd ed.). American Management Association: New York.

Rosemary-Batt, A. J. (Jul., 2002). Employee Voice, Human Resource Practices, and Quit Rates: Evidence from the Telecommunica- tions Industry. Industrial and Labour Relations Review, 55(4), 573-594.

Hassan A. D. \& Siddiqui, A. S. (2019). Impact of Effective Succession Planning Practices on Employee Retention: Exploring the Mediating Roles. International Journal of $\mathrm{Hu}$ man Resource Studies, 10(2), 21-55.

Salaman, G. T. (2014). Relationship between succession planning practices and employee retention in large media houses in Kenya. Unpublished Manuscript, University of Nairobi: Kenya.

Sambrook, S. (2005). Exploring succession planning in small, growing firms. Journal of Small Business and Enterprise Development, 12(4), 79-594.

Shepard, K. (2008). The Rigour of Requisite Organisation. Retrieved on September 20, 2016 from http://irc.queensu.ca/articles/ rigour-requisite-organisation.

Tabachnick, B \& Fidel, L. (2001). Using Multivariate Statistics. Boston: Allen \& Bacon

Taylor, S. (2002). People Resourcing. CIPD.

Tunje, G. S. (2014). Relationship between Succession Planning Practices and Employee Retention in Large Media Houses in Kenya. Unpublished Dissertation, School of Business: University of Nairobi.

Yanney, John. (2017). Importance of succession planning practices on organizational performance on Ghanaian SMEs: The Conceptual Framework. Research Gate. Retrieved on December 12, 2017 from https://www.researchgate.net/publication /319965120

Yuorpor M. J. (2013). Organisational Culture, Worker Autonomy and Employee Innovativeness. Unpublished manuscript. University of Ghana, Accra 